\title{
Grapeseed Meal Used as Natural Antioxidant in High Fatty Acid Diets for Hubbard Broilers
}

http://dx.doi.org/10.1590/1806-9061-2018-0886

-Author(s)

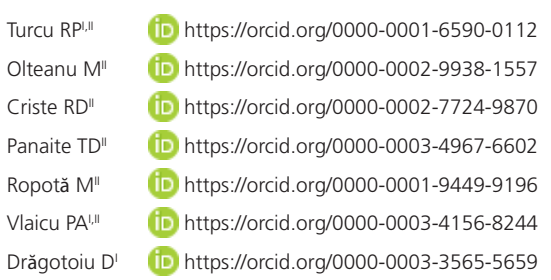

University of Agronomic Sciences and Veterinary Medicine of Bucharest, 59 Marasti Blvd, District 1 Bucharest, Romania.

" National Research-Development Institute for Animal Biology and Nutrition (IBNA), 1 Calea Bucuresti, Balotesti, 077015, Ilfov, Romania.

\section{-Mail Address}

Corresponding author e-mail address Dr Olteanu Margareta

Department of Chemistry and Nutrition Physiology, National Research

Development Institute for Animal Biology and Nutrition, 1 Calea Bucuresti, Balotesti, 077015, llfov, Romania.

Phone: (+40) 0213512082

Email: margaretaolteanu@yahoo.com

\section{aKeywords}

Grapeseed meal, natural antioxidant, PUFA.

\section{ABSTRACTO}

The 7-week feeding trial evaluated the effect of $2 \%$ grapeseed meal used as natural antioxidant in the diets for slow-growing Hubbard broiler chicks, aged 14 days. The chicks were weighed individually and assigned to two groups ( $C$ and $E$ ), with 40 chicks per group, housed under conditions of temperature, humidity and light regimen according to the hybrid management guide. The basal ingredients of the conventional diet were corn, wheat, gluten, soybean meal and $2 \%$ flaxseed meal, which is rich in polyunsaturated fatty acids. Compared to the control formulation, the experimental formulation included $2 \%$ grapeseed meal, both in the growing and finishing stages. The broilers had free access to feed and water. In the end of the feeding trial, blood samples were collected for serum biochemical determinations and six broilers per group were slaughtered and samples of breast and thigh meat were collected. The meat samples were assayed for the basic chemical composition, fatty acids profile and cholesterol content using standardized methods. The content of total polyunsaturated fatty acids (PUFAs) was significantly higher $(p<0.05)$ in breast samples, while cholesterol content was significantly lower $(p<0.05)$ in thigh samples from E group, compared to $C$. Blood glucose, cholesterol and triglyceride levels were significantly lower $(p<0.05)$ in group $E$ than in group $C$. The study showed that the grapeseed meal used as natural antioxidant in broiler diets enriched in polyunsaturated fatty acids given to Hubbard broilers had beneficial effects on broiler meat quality and on the metabolic profile of the blood plasma.

\section{INTRODUCTION}

Changes in human diets over the past 100 to 150 years, particularly in terms of dietary fat intake and its effect on human health has become a major concern in nutrition research (Ayerza et al., 2002). Chicken meat is low in fat and cholesterol and is usually considered healthier than other animal protein sources, especially red meats of mammalian origin (Ponte et al., 2004). The use of raw materials high in polyunsaturated fatty acids in the diets for farm animals with the view of obtaining foods with high nutritional value, with beneficial effects on consumer health, can be done rather easily by feeding. A good way to raise the omega-3 PUFA content in the diet, without making radical changes in the eating habits, seems to be the enrichment of frequently consumed food products. Flaxseed meal is a rich source of alphalinolenic acid (ALA). ALA is an essential fatty acid in the human diet and is converted into two main long chain fatty acids, eicosapentaenoic acid and docosahexaenoic acid in a series of enzymatic reactions (Tapiero et al., 2002). The fats, however, are likely to cause the feeds to get rancid (Ren et al., 2013), which damages their quality, hence their acceptance by the animals. 
Turcu RP, Olteanu M, Criste RD, Panaite TD, Ropotă M, Vlaicu PA, Drăgotoiu D
Grapeseed Meal Used as Natural Antioxidant in High Fatty Acid Diets for Hubbard Broilers
Millions of tons of grapes are currently produced each year, and about $15 \%$ of the production is used by wineries. This socio-economic activity generates a large amount of solid waste, which represents up to $30 \%$ of the weight of the used material (Teixeira et al., 2014). This calls for a higher use of these winery by-products, which contain active biocompounds with antioxidant properties (Radovanovic et al., 2009; Granato et al., 2010), as raw materials for pharmaceutics, cosmetics, food industry and feed additives. Grape seed flour, the residue from seed oil manufacture, has not received much attention but may be a potential rich source of natural antioxidants and other healthful bioactive compounds (Luther et al., 2007). Grape seeds have about $15 \%$ of the solid waste produced in wine and are increasingly recognized as products that require a more accurate analysis of their value (Luque-Rodríguez et al., 2005).

The literature has several studies reporting the use of winery by-products in broiler feeding and their effect on broiler performance, on protein and amino acids digestibility, on the gut microflora and on meat quality. Viveros et al. (2011) investigated the effects of dietary polyphenol-rich grape products on the intestinal microflora and gut morphology in broilers and concluded that winery by-products modify gut morphology and intestinal microflora and increase the biodiversity of the intestinal bacteria in broilers. Kasapidou et al. (2013) evaluated the effect of grape pomace supplementation on broiler meat quality characteristics. The inclusion of grape pomace in the diet did not affect lipid oxidation levels in breast and thigh muscle during storage. On the basis of microbiological data, there was neither a clear nor a consistent effect of grape pomace supplementation on poultry meat microbiological status. The inclusion of grape pomace in broiler diets did not affect the eating quality of the breast muscle. Fakhraddin \& Shahria (2014) also evaluated the effect of red grape pomace on the performance, lipid peroxidation (MDA) and some serum biochemical parameters in broilers. They concluded that the supplementation of red grape pomace in broiler diets decreased broiler performance linearly after 2\%. Grape pomace decreased blood glucose level, total antioxidant and MDA. Therefore, grape pomace can be used in broiler diets expecting to increase insolubility and decrease cholesterol and triglyceride in plasma. This is also important for the safety of meat consumers.

The purpose of our study was to evaluate the effect of $2 \%$ grapeseed meal added to a broiler diet rich in polyunsaturated fatty acids on broiler performance, meat quality and on the metabolic profile of the blood plasma in slow-growing Hubbard broilers, at the end of the feeding trial.

\section{MATERIAL AND METHODS}

\section{Birds and experimental design}

The feeding trial was conducted in the experimental halls of the National Research-Development of Animal Biology and Nutrition (IBNA-Balotesti, Romania) according to a protocol approved by the Commission of Ethics of our institute. The 7-week feeding trial was conducted on 80, Hubbard broiler chicks with slow growth, aged 14 days. They were weighed individually and assigned to two groups, C and E (40 chicks per group), with an initial weight of $233.38 \pm 6.14 \mathrm{~g}$ (C), $233.25 \pm 6.53 \mathrm{~g}(\mathrm{E})$, without significant differences ( $p>0.05$ ) between the groups. The chicks were housed in an experimental hall raised to the ground under $22-24^{\circ} \mathrm{C}$ normal conditions of temperature, with 60 $-70 \%$ humidity and $23 \mathrm{~h}$ light regimen throughout the experimental period, according to the_Hubbard CLASSIC Management Guide. They had free access to the feed and water. The following parameters were monitored throughout the experimental period (14 63 days): initial weight (g), final weight (g), average daily feed intake (g feed/broiler/day), average daily weight gain (g/broiler/day) and feed conversion ratio (g feed/g gain).

\section{Diet formulation}

The diet formulation was calculated using the results of the chemical analysis of the feed ingredients in agreement with the feeding requirements (NRC, 1994) and using a mathematical model for poultry diets formulation (Burlacu et al., 1999). The basal ingredients of both conventional diets (Table 1), grower phase (14 - 28 days) and finisher phase (2963 days) were: corn, wheat, gluten, soybean meal and $2 \%$ flaxseeds meal, which is rich in polyunsaturated fatty acids. The experimental diet (E) was differed from the control diet (C) by the inclusion of $2 \%$ grapeseed meal, as natural antioxidant, purchased from 2E Prod SRL Alexandria, Teleorman County.

\section{Sampling and analysis}

The grapeseed meal was analysed for the primary chemical composition, polyphenols content and antioxidant capacity. A single batch of compound feed was manufactured for each group and growth period 
Table 1 - Diet formulation (\%)

\begin{tabular}{|c|c|c|c|c|}
\hline \multirow{2}{*}{ Specification } & \multicolumn{2}{|c|}{$\begin{array}{c}\text { Grower } \\
(14-28 \text { days })\end{array}$} & \multicolumn{2}{|c|}{$\begin{array}{c}\text { Finisher } \\
(29-63 \text { days })\end{array}$} \\
\hline & C & $E$ & C & $E$ \\
\hline Corn & 49.92 & 45.14 & 44.26 & 48.56 \\
\hline Wheat & 15.00 & 15.00 & 16.00 & 10.00 \\
\hline Corngluten & 4.00 & 4.00 & 4.00 & 3.50 \\
\hline Soybean meal & 19.85 & 22 & 24.00 & 24.00 \\
\hline Flax meal & 2.00 & 2.00 & 2.00 & 2.00 \\
\hline Grapeseed meal & - & 2.00 & 0.00 & 2.00 \\
\hline Sunflower oil & 4.40 & 5.00 & 5.00 & 5.20 \\
\hline Monocalcium phosphate & 1.32 & 1.50 & 1.30 & 1.40 \\
\hline Calcium carbonate & 1.73 & 1.62 & 1.70 & 1.60 \\
\hline Salt & 0.34 & 0.34 & 0.34 & 0.34 \\
\hline Methionine & 0.15 & 0.15 & 0.15 & 0.15 \\
\hline Lysine & 0.24 & 0.20 & 0.20 & 0.20 \\
\hline Choline & 0.05 & 0.05 & 0.05 & 0.05 \\
\hline Vitamin-mineral premix (PVM)* & 1.00 & 1.00 & 1.00 & 1.00 \\
\hline TOTAL & 100 & 100 & 100 & 100 \\
\hline \multicolumn{5}{|l|}{ Analysed composition } \\
\hline Gross energy, MJ/kg & 16.83 & 17.04 & 17.61 & 18.05 \\
\hline Dry matter, $\%$ & 90.18 & 90.72 & 89.81 & 90.04 \\
\hline Crude protein, \% & 20.19 & 20.30 & 19.84 & 20.29 \\
\hline Lysine, g/ $100 \mathrm{~g} \mathrm{DM}$ & 0.990 & 1.142 & 1.331 & 1.429 \\
\hline Methionine, g/ $100 \mathrm{~g} \mathrm{DM}$ & 0.433 & 0.363 & 0.376 & 0.406 \\
\hline Calcium, \% & 0.91 & 0.91 & 0.91 & 0.90 \\
\hline Phosphorus, \% & 0.81 & 0.75 & 1.27 & 0.88 \\
\hline Saturated fatty acids (SFA), \% & 11.04 & 11.14 & 14.74 & 14.75 \\
\hline Monounsaturated fatty acids (MUFA), \% & 23.62 & 21.94 & 24.11 & 24.23 \\
\hline Unsaturated fatty acids (UFA), \% & 88.96 & 88.86 & 84.96 & 84.98 \\
\hline Polyunsaturated fatty acids (UFA), \% & 65.33 & 66.92 & 60.86 & 60.75 \\
\hline SFA/UFA & 0.12 & 0.13 & 0.17 & 0.17 \\
\hline PUFA/MUFA & 2.77 & 3.05 & 2.52 & 2.51 \\
\hline
\end{tabular}

*1 kg premix contains: $=1100000 \mathrm{IU} / \mathrm{kg}$ vit. A; $200000 \mathrm{IU} / \mathrm{kg}$ vit. D3; $2700 \mathrm{IU} / \mathrm{kg}$ vit. E; $300 \mathrm{mg} / \mathrm{kg}$ vit. K; $200 \mathrm{mg} / \mathrm{kg}$ vit. B1; $400 \mathrm{mg} / \mathrm{kg}$ vit. B2; $1485 \mathrm{mg} / \mathrm{kg}$ pantothenic acid; 2700 $\mathrm{mg} / \mathrm{kg}$ nicotinic acid; $300 \mathrm{mg} / \mathrm{kg}$ vit. B6; $4 \mathrm{mg} / \mathrm{kg}$ vit. B7; $100 \mathrm{mg} / \mathrm{kg}$ vit. B9; $1.8 \mathrm{mg} / \mathrm{kg}$ vit. B12; $2000 \mathrm{mg} / \mathrm{kg}$ vit. C; $8000 \mathrm{mg} / \mathrm{kg}$ manganese; $8000 \mathrm{mg} / \mathrm{kg}$ iron; $500 \mathrm{mg} / \mathrm{kg}$ copper; $6000 \mathrm{mg} / \mathrm{kg}$ zinc; $37 \mathrm{mg} / \mathrm{kg}$ cobalt; $152 \mathrm{mg} / \mathrm{kg}$ iodine; $18 \mathrm{mg} / \mathrm{kg}$ selenium.

(finishing); compound feed samples were collected and assayed for the primary chemical composition.

The collected samples were assayed for the dry matter, crude protein, ether extractives, fibre and ash using standardized methods according to Regulation (EC) no. 152/2009 for compound feeds. Dry matter (DM)was determined with the gravimetric method using Sartorius (Gottingen, Germany) scales and BMT ECOCELL Blueline Comfort (Nuremberg, Germany) drying oven; crude protein (CP) was determined using the Kjeldahl method, using a semiautomatic KJELTEC auto 2300 system - Tecator (Sweden); the ether extractives (EE) were determined by extraction in organic solvents with a SOXTEC-2055 system, FOSS -Tecator (Sweden); ash (Ash) was determined with the gravimetric method using Caloris CL 1206 furnace. Gross energy (GE) was determined by calculation, using the gross chemical composition, with the equations of Burlacu et al. (2002).
Polyphenols concentration and antioxidant capacity of the tested compound feeds. The polyphenols concentration was determined with the method described by Mihailovic et al. (2013). The phenol compounds were first extracted in acidified methanol (methanol: $\mathrm{HCl}=80: 20$ ), and then determined with a UV-VIS Thermo Scientific spectrophotometer. The results were expressed in $\mathrm{mg}$ gallic acid equivalents/ $\mathrm{g}$ sample (mg GAE / g sample). The determination of the antioxidant capacity of the methanol extracts has been done using the DPPH method, proposed by Marxen et al. (2007), using a UV-VIS Analytik Jena Specord 250 Plus spectrophotometer with thermostatic carousel. The results were expressed in Trolox equivalents/g sample (mM TE/ g sample).

Metabolic profile of the broilers blood plasma. The blood biochemical parameters were determined in the end of the experimental period on blood samples collected in $6 \mathrm{ml}$ Vacutainer tubes on Heparin - Lithium 
anticoagulant. The blood biochemical parameters were determined from the plasm obtained by blood samples centrifugation at 3,000 rpm, for $20 \mathrm{~min}$ at $+22^{\circ} \mathrm{C}$. The plasm was stored in a deep freezer at $-80^{\circ} \mathrm{C}$ until analysed. The plasm energy (glycaemia, cholesterol, triglycerides), proteic (protein, albumin, creatinine, urea) and mineral (calcium, phosphor, magnesium, iron) profiles were determined from the plasm samples, using a biochemical analyser (Analyzer Chemisty Mindray BS -130) with ACCENT -200 kits, according to the manufacturer's instructions.

Six broilers per group were slaughtered at the end of the feeding trial (63 days, broiler age), according to the working protocol approved by the Ethics commission from IBNA Balotesti; six breast meat samples and six thigh meat samples per group were formed and used to determine the fatty acids profile, the cholesterol level and the fat degradation indicators.

Fatty acids content of the broiler meat samples. The fatty acids were determined by gas-chromatography, according to SR CEN ISO/TS 17764-2:2008 standard, using a Perkin Elmer-Clarus 500 chromatograph, with on-column injector, with high polarity stationary phase (BPX70: $60 \mathrm{~m} \times 0.25 \mathrm{~mm}$ inner diameter and 0,25 $\mathrm{mm}$ film thickness); or high polarity cyanopropyl phase with similar resolution for various geometric isomers (THERMO TR-Fame: $120 \mathrm{~m} \times 0.25 \mathrm{~mm}$ ID $\times 0.25 \mu \mathrm{m}$ film). The results were expressed in $\mathrm{g}$ fatty acids $/ 100$ $\mathrm{g}$ fat.

Fat degradation indicators of meat samples. The peroxide value for the meat samples was determined with the iodometric method, according to SR EN ISO 3960:2017, while fat acidity was determined with the volumetric method, according to ISO 660:2009.

Cholesterol level in the broiler meat samples. The cholesterol level of the breast and thigh meat samples was determined by gas-chromatography, according to AOAC International 1996 AOAC Official Method 99410: Cholesterol in food, Perkin Elmer-Clarus 500 chromatograph, with on-column injector (splitting ratio, about 1:100), with programmable column heater; flame ionization detector (FID) and capillary separation column HP-5 (30m, 0.32 mm ID, $0.1 \mu \mathrm{m}$ film) Agilent.

\section{Statistical analysis}

The effects of treatments were tested using ANOVA GLM procedure of Minitab software (version 17, Minitab ${ }^{\circledR}$ Statistical Software), with treatment as a fixed effect, according to the model $\mathrm{Yi}=\mathrm{Ti}+\mathrm{ei}$, where $\mathrm{Yi}$ was the dependent variable, $\mathrm{Ti}$ is the treatment and ei is the error. When overall F-test was significant, differences between means were declared significant at $p<0.05$ using the Tuckey comparison test.

\section{RESULTS}

\section{Chemical composition}

The flaxseed meal (Table 2), raw material rich in fatty acids, had $34.44 \%$ crude protein, $10.97 \%$ ether extractives and $20.20 \mathrm{MJ} / \mathrm{kg}$ gross energy. The fatty acids profile was as follows: $11.21 \mathrm{~g}$ SFA, $20.00 \mathrm{~g}$ MUFAs, $68.92 \mathrm{~g}$ PUFAs, of which $53.35 \mathrm{~g}$ omega-3 PUFAs, and $15.57 \mathrm{~g}$ omega-6 PUFAs / $100 \mathrm{~g}$ total fatty acids, and omega-6/ omega-3 of 0.29 .

Table 2 - Content of the main nutrients of grapeseed meal and flaxseed meal.

\begin{tabular}{lcc}
\hline Specification & Grapeseed meal & Flaxseed meal \\
\hline Crude protein, \% & 12.90 & 34.44 \\
Ether extractives, \% & 7.22 & 10.97 \\
Gross energy, MJ/kg & 18.55 & 20.20 \\
SFA & 12.30 & 11.21 \\
MUFA & 20.39 & 20.00 \\
PUFA & 67.14 & 68.92 \\
$\Omega 3, \%$ & 0.68 & 53.35 \\
$\Omega 6, \%$ & 66.45 & 15.57 \\
\hline
\end{tabular}

SFA- saturated fatty acids; MUFA- monounsaturated fatty acids; PUFA-polyunsaturated fatty acids; $\Omega 3$ - omega 3 polyunsaturated fatty acids; $\Omega 6$ - omega 6 polyunsaturated fatty acids.

The natural antioxidant, the grapeseed meal (Table 2 ), had $12.90 \%$ crude protein, $7.22 \%$ ether extractives, $18.55 \mathrm{MJ} / \mathrm{kg}$ gross energy, $26.65 \mathrm{mg} \mathrm{GAE} / \mathrm{g}$ polyphenols, and an antioxidant capacity of $148.35 \mathrm{mM} \mathrm{TE} / \mathrm{g}$. The use of $2 \%$ grapeseed meal as natural antioxidant in the experimental diet (E) (Table 3 ) increased significantly $(p<0.05)$, by $18.12 \%$, the polyphenols concentration, and by $36.43 \%$ the antioxidant capacity, compared to the control diet (C). The fatty acids profile was: $12.30 \mathrm{~g}$ SFA, $20.39 \mathrm{~g}$ MUFAs, $67.14 \mathrm{~g}$ PUFAs, of which $0.68 \mathrm{~g}$ omega-3 PUFAs, and $66.45 \mathrm{~g}$ omega-6 PUFAs / $100 \mathrm{~g}$ total fatty acids.

Table 3 - Concentration of polyphenols and antioxidant capacity of the tested compound feeds*.

\begin{tabular}{llll}
\hline Specification & $C$ & $E$ & SEM \\
Concentration of polyphenols, mg gallic acid equivalents/g & $1.60^{\text {a }}$ & $1.89^{\mathrm{b}}$ & 0.080 \\
\hline Antioxidant capacity, mM Trolox equivalents/g & $2.47^{\mathrm{a}}$ & $3.37^{\mathrm{b}}$ & 0.0493 \\
\hline
\end{tabular}

${ }^{a-b}$ Mean values within a row having different superscripts are significantly different by least significant difference test $(p<0.05)$. SEM-standard error of the mean. 


\section{Broilers performance}

Regarding broiler performance throughout the experimental period (14-63 days), Table 4 shows no significant $(p>0.05)$ differences between the groups.
E broilers had the highest average final body weight $(2719.47 \pm 71.02 \mathrm{~g})$, the highest average daily body weight gain ( $50.74 \pm 3.20 \mathrm{~g} /$ day/ broiler) and the best feed conversion ratio, $2.31 \pm 0.34 \mathrm{~g}$ feed/ $\mathrm{g}$ gain.

Table 4 - Broiler performance for the whole experimental period (14 - 63 days)*

\begin{tabular}{lcccc}
\hline Specification & $C$ & E & SEM & $p$-value \\
\hline Average daily feed intake, g feed/broiler/day & $114.21^{\mathrm{a}}$ & $117.09^{\mathrm{a}}$ & 3.912 & 0.7149 \\
Initial weight, g & $233.37^{\mathrm{a}}$ & $233.25^{\mathrm{a}}$ & 4.453 & 0.9889 \\
Final weight, g & $2545.00^{\mathrm{a}}$ & $2719.47^{\mathrm{a}}$ & 50.903 & 0.0866 \\
Average daily weight gain, g/broiler/day & $47.18^{\mathrm{a}}$ & $50.74^{\mathrm{a}}$ & 1.037 & 0.0900 \\
Feed conversion ratio, g feed/g gain & $2.42^{\mathrm{a}}$ & $2.31^{\mathrm{a}}$ & 0.265 & 0.8383 \\
\hline
\end{tabular}

${ }^{\mathrm{a}}=$ Not significant difference $(p>0.05)$. SEM: standard error of the mean.

\section{Metabolic profile of the blood plasma}

Table 5 shows the metabolic profile of the blood plasma collected from the broilers slaughtered at 63 days of age. As it can be noticed, the values of the energy profile are significantly lower $(p<0.05)$ in the experimental group, treated with grapeseed meal, compared to the control group. Glycaemia decreased by $18.58 \%$, cholesterol by $30.24 \%$, and the triglycerides by $25.57 \%$, compared to group $C$. There were no significant $(p>0.05)$ differences in the protein profile of the broiler meat, but the concentration of each parameter was higher in group $\mathrm{E}$ than in group $\mathrm{C}$. The values of the mineral profile were significantly $(p<0.05)$ different between the two groups. The calcium level was higher by $4.67 \%$, the phosphorus level by $39.72 \%$, and the iron level by $35.26 \%$ in group $E$ than in group $C$.

Table 5 - Metabolic profile of the blood plasma for broilers aged 63 days.

\begin{tabular}{|c|c|c|c|c|c|}
\hline \multicolumn{2}{|c|}{ Specification } & \multirow{2}{*}{$\frac{C}{271.03^{a}}$} & \multirow{2}{*}{$\frac{E}{220.67^{b}}$} & \multirow{2}{*}{$\frac{\text { SEM }}{7.917}$} & \multirow{2}{*}{$\begin{array}{l}p \text {-value } \\
<0.0001\end{array}$} \\
\hline & Glycaemia, mg/dl & & & & \\
\hline के & Cholesterol, mg/dl & $146.81^{\mathrm{a}}$ & $102.41^{b}$ & 7.021 & $<0.0001$ \\
\hline 岀 & Triglycerides, mg/dl & $49.93^{a}$ & $37.16^{b}$ & 2.213 & 0.0002 \\
\hline \multirow{4}{*}{$\begin{array}{l}. \frac{5}{0} \\
\frac{0}{0} \\
\frac{0}{2}\end{array}$} & Total protein, g/dl & $2.27^{\mathrm{a}}$ & $2.38^{a}$ & 0.052 & 0.3093 \\
\hline & Albumin, mg/dl & $1.11^{\mathrm{a}}$ & $1.16^{\mathrm{a}}$ & 0.027 & 0.3939 \\
\hline & Creatinine, mg/dl & $0.37^{\mathrm{a}}$ & $0.41^{\mathrm{a}}$ & 0.017 & 0.2936 \\
\hline & Urea, mg/dl & $6.19^{a}$ & $6.17^{a}$ & 0.292 & 0.9725 \\
\hline \multirow{4}{*}{ 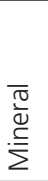 } & Calcium, mg/dl & $5.78^{\mathrm{a}}$ & $6.05^{\mathrm{a}}$ & 0.160 & 0.6027 \\
\hline & Phosphorus, mg/dl & $3.65^{\mathrm{a}}$ & $5.10^{b}$ & 0.279 & 0.0027 \\
\hline & Magnesium, mg/dl & $2.72^{\mathrm{a}}$ & $2.88^{a}$ & 0.163 & 0.6400 \\
\hline & Iron, $\mu \mathrm{g} / \mathrm{dl}$ & $61.00^{a}$ & $82.51^{b}$ & 4.139 & 0.0026 \\
\hline
\end{tabular}

${ }^{a-b}$ Mean values within a row having different superscripts are significantly different by least significant difference test $(p<0.05)$. SEM-standard error of the mean.

\section{Breast and thigh meat fatty acid content}

Table 6 shows the fatty acids content in the fat from the breast and thigh meat samples. The breast meat content of total PUFAs was significantly $(p<0.05)$ higher in group $E$ (by $5.48 \%$ ) than in group C; at the same time, the content of omega- 6 PUFAs was also significantly $(p<0.05)$ higher in group E (by $5.27 \%$ ) than in group $C$. The breast meat content of ALA was $1.82 \mathrm{~g}$ in group $C$ and $1.97 \mathrm{~g} / 100 \mathrm{~g}$ total fatty acids in group $\mathrm{E}$. The thigh meat content of omega-3, omega-6 PUFAs and total PUFAs was higher in group E compared to group $C$, but the difference was not statistically different $(p>0.05)$.

\section{The evolution of the fat degradation indices at slaughter}

Table 7 shows the evolution of the fat degradation indices at slaughter. The data show that, after 7 days of refrigeration at $+4{ }^{\circ} \mathrm{C}$, the peroxide value in the breast was significantly $(p<0.05)$ lower, by $9.09 \%$, in group $E$, than in group $C$. After one month of freezing, the decrease of the peroxide value in group $E$ samples was not significant compared to group $\mathrm{C}$ samples. The same situation is with fat acidity, which was lower in group $E$, both after 7 days of refrigeration, and after one month of freezing; however, the difference was not statistically different $(p>0.05)$. The peroxide value 
Table 6 - Fatty acids content of the broiler meat samples according to the level of unsaturation $(\mathrm{g}$ acid/100 $\mathrm{g}$ total fatty acids).*

\begin{tabular}{|c|c|c|c|c|c|c|c|c|}
\hline \multirow{2}{*}{ Fatty acids } & \multicolumn{4}{|c|}{ Breast } & \multicolumn{4}{|c|}{ Thigh } \\
\hline & $C$ & $E$ & SEM & $p$-value & $C$ & $E$ & SEM & $p$-value \\
\hline SFA & $32.48^{\mathrm{a}}$ & $32.47^{a}$ & 0.132 & 0.9719 & $30.97^{a}$ & $30.51^{a}$ & 0.218 & 0.3146 \\
\hline MUFAs & $39.09^{a}$ & $37.76^{b}$ & 0.271 & 0.0052 & $38.40^{\mathrm{a}}$ & $38.37^{a}$ & 0.285 & 0.9632 \\
\hline $\begin{array}{l}\text { PUFAs, } \\
\text { of which: }\end{array}$ & $27.73^{a}$ & $29.25^{b}$ & 0.370 & 0.0310 & $30.06^{a}$ & $30.59^{a}$ & 0.519 & 0.6359 \\
\hline$\omega-3$ & $2.80^{a}$ & $2.93^{\mathrm{a}}$ & 0.067 & 0.3530 & $3.00^{a}$ & $3.19^{a}$ & 0.087 & 0.3000 \\
\hline$\omega-6$ & $24.84^{a}$ & $26.15^{b}$ & 0.316 & 0.0292 & $27.03^{a}$ & $27.28^{a}$ & 0.447 & 0.7903 \\
\hline$\omega-6 / \omega-3$ & $8.90^{\mathrm{a}}$ & $8.98^{a}$ & 0.162 & 0.8631 & $9.07^{a}$ & $8.56^{a}$ & 0.158 & 0.1094 \\
\hline
\end{tabular}

"Where:SFA- saturated fatty acids; MUFAs- monounsaturated fatty acids; PUFAs- polyunsaturated fatty acids; ALA- $\alpha$-linolenic acid; $\omega$ - 3 - omega-3 polyunsaturated fatty acids; $\omega$ -6 - omega-6 polyunsaturated fatty acids.

a-b Mean values within a row having different superscripts are significantly different by least significant difference test $(p<0.05)$. SEM-standard error of the mean.

Table 7 - Evolution of the fat degradation indices in the broiler meat.

\begin{tabular}{|c|c|c|c|c|c|}
\hline \multirow{2}{*}{ Specification } & \multicolumn{5}{|c|}{ Breast meat } \\
\hline & Period & C & $E$ & SEM & $p$-value \\
\hline \multirow{2}{*}{$\begin{array}{l}\text { Peroxide value } \\
\text { (ml thiosulfate } 0.1 \mathrm{~N} / \mathrm{g} \text { fat) }\end{array}$} & day 7- refrigeration & $0.88^{a}$ & $0.80^{\mathrm{b}}$ & 0.013 & $<0.0001$ \\
\hline & 1 month - freezing & $0.50^{\mathrm{a}}$ & $0.51^{\mathrm{a}}$ & 0.002 & 0.0369 \\
\hline \multirow{4}{*}{$\begin{array}{l}\text { Fat acidity } \\
\text { (mg KOH / g fat) }\end{array}$} & day 7- refrigeration & $36.42^{\mathrm{a}}$ & $36.19^{a}$ & 0.153 & 0.4827 \\
\hline & 1 month - freezing & $20.89^{a}$ & $20.09^{a}$ & 0.337 & 0.2524 \\
\hline & \multicolumn{5}{|c|}{ Thigh meat } \\
\hline & Period & C & $E$ & SEM & $p$-value \\
\hline \multirow{2}{*}{$\begin{array}{l}\text { Peroxide index } \\
\text { (ml thiosulfate } 0.1 \mathrm{~N} / \mathrm{g} \text { fat) }\end{array}$} & day 7- refrigeration & $1.12^{\mathrm{a}}$ & $1.11^{\mathrm{a}}$ & 0.010 & 0.5428 \\
\hline & 1 month - freezing & $0.63^{a}$ & $0.62^{a}$ & 0.005 & 0.2071 \\
\hline \multirow{2}{*}{$\begin{array}{l}\text { Fat acidity } \\
\text { (mg KOH / g fat) }\end{array}$} & day 7- refrigeration & $43.99^{a}$ & $41.05^{b}$ & 0.594 & 0.0053 \\
\hline & 1 month - freezing & $24.23^{\mathrm{a}}$ & $20.77^{b}$ & 0.622 & 0.0007 \\
\hline
\end{tabular}

a-b Mean values within a row having different superscripts are significantly different by least significant difference test $(p<0.05)$. SEM-standard error of the mean.

in the thigh meat, after 7 days of refrigeration at $+4^{\circ} \mathrm{C}$, and after one month of freezing, was lower in group $\mathrm{E}$ than in group $C$, but the difference was not statistically different ( $p>0.05)$. However, fat acidity decreased significantly $(p<0.05)$ in group $E$, both after 7 days of refrigeration at $+4^{\circ} \mathrm{C}$ (by $6.68 \%$ ), and after one month of freezing, by $14.27 \%$, compared to group C

\section{Cholesterol level}

Table 8 shows that the cholesterol level in the fat from the breast meat samples was $8.13 \%$ lower in the experimental group compared to the control group, but the difference was not statistically significant ( $p>0.05)$. The thigh meat samples, however, showed a significantly $(p<0.05)$ lower concentration of cholesterol in group E (by $23.85 \%$ ), compared to group C.

\section{DISCUSSION}

Because the analysis of the primary chemical composition is the starting point in any experiment it is importance to characterize the by-products which will be used in the diet formulation (Table 2). The primary chemical composition of the winery by-products varies with the processing technology, cultivar, soil composition, climate, geographic origin, and cultivation practices or exposure to diseases, such as fungal infections (Bruno \& Sparapano, 2007). The determined chemical composition of the grapeseed meal used in this experiment $(12.90 \%$ crude protein, $7.22 \%$ ether extractives, $18.55 \mathrm{MJ} / \mathrm{kg}$ gross energy) is similar with the results from other research which tested this by-product in broilers diet. Olteanu et al. (2018), in a study on the antioxidant role of the grapeseed meal

Table 8 - Cholesterol level in the broiler meat samples (mg/ $100 \mathrm{~g}$ ).

\begin{tabular}{llllll}
\hline Specification & & $\mathrm{C}$ & $\mathrm{E}$ & SEM & $\mathrm{p}$-value \\
\hline \multirow{2}{*}{ Cholesterol } & Breast meat & $44.28^{\mathrm{a}}$ & $40.68^{\mathrm{a}}$ & 1.100 & 0.1026 \\
& Thigh meat & $60.91^{\mathrm{a}}$ & $46.38^{\mathrm{b}}$ & 3.278 & 0.0176 \\
\hline
\end{tabular}

${ }_{\text {a-b }}$ Mean values within a row having different superscripts are significantly different by least significant difference test $(p<0.05)$. SEM-standard error of the mean; means in the same row no common superscript significantly different $(p<0.05)$. 
Turcu RP, Olteanu M, Criste RD, Panaite TD, Ropotă M, Vlaicu PA, Drăgotoiu D
Grapeseed Meal Used as Natural Antioxidant in High Fatty Acid Diets for Hubbard Broilers in preventing the degradation of high-fatty acid broiler diets, used different levels of grapeseed meal inclusion (2\% and 3 ) and 2\% flax seed meal. The reported data for the basic chemical composition of grapeseed meal were $12.76 \%$ protein, $7.13 \%$ ether extractives and $35.30 \%$ crude fibre. In a research regarding the feeding value of some food industry by-products (Panaite et al., 2016), grapeseed meals showed a content of $89.16 \%$ dry matter, $11.91 \%$ crude protein, $5.96 \%$ ether extractives and $35.68 \%$ fibre.

Among the bioactive compounds of the grapes, phenols represent the third most abundant constituent in grapes after carbohydrates and fruit acids (Singleton, 1980), they accumulate in solid parts of grapes, namely seeds, skins and clusters (Mironeasa, 2017). The grapeseed meal used in this study showed similar polyphenol concentration (26.65 mg GAE/ g) and antioxidant capacity ( $148.35 \mathrm{mM}$ TE/ g) with those from the literature. The investigations regarding the biological activities of polyphenols reported values from $36.6 \mathrm{mg} \mathrm{GAE} / \mathrm{g}$ to $49.7 \mathrm{mg} \mathrm{GAE} / \mathrm{g}$ DW in the grape seed extract (Ky et al., 2014), to 2178.8, 374.6, 23.8, and $351.6 \mathrm{mg} / \mathrm{g}$ GAE in seed, skin, flesh, and leaf (Pastrana-Bonilla et al., 2003). Being most notable the bioactivity of phenolic compounds from grapes, the antioxidative characteristics have been widely studied (Meyer et al., 1997). The antioxidant capacity data from literature show 16.8 - 92 mM Trolox equivalents (TE) /g sample for the grape seeds, $15.7-113.3 \mathrm{mM}$ TE/ $\mathrm{g}$ sample for the grape peel (En-Qin Xian et al., 2010), $3.186 \mathrm{mg}$ in the grape pomace (Poudel et al., 2008) and $493.07 \mathrm{mMTrolox} / \mathrm{g}$ sample in the grapeseed meal (Panaite et al., 2016).

The work presented in this paper showed that grapeseed meal incorporation (2\%) into Hubbard broilers diet was able to increase the polyphenol concentration and antioxidant capacity (Table 3 ) in the experimental group (E), compared to the control group (C). It should be mentioned that broiler performance (Table 4) for the entire experimental period (14-63 days) was not affected by the dietary grapeseed meal, and that the final weight of $E$ broilers was higher than that of $C$ broilers. The literature data regarding the influence of the dietary winery by-products on the bioproductive performance is varied. Viveros et al., (2011) studied the effect of the inclusion of grape pomace concentrate and grape seed extract in the diet of broilers. Dietary treatments included an antibiotic-free diet, a positive control (50 mg/kg of avoparcin), and antibiotic-free diets containing grape pomace concentrate $(60 \mathrm{~g} /$ $\mathrm{kg})$ or grapeseed extract $(7.2 \mathrm{~g} / \mathrm{kg})$. The reported data showed that broiler performance was not affected by dietary treatment, except for the grapeseed extract diet $(7.2 \mathrm{~g} / \mathrm{kg})$, which showed a decreased weight gain and feed efficiency. Growth performance was depressed in chicks fed the grapeseed extract diet compared with those fed the grape pomace concentrate diet $(60 \mathrm{~g} /$ $\mathrm{kg}$ ). Wang et al., 2008 concluded in a study that the incorporation of grapeseed extract as low as 10 to 20 $\mathrm{mg} / \mathrm{kg}$ in broiler diets is able to enhance the growth performance of broilers and significantly reduce the mortality of chicks after the E. tenella infection. On the other hand, Abu et al. (2018) reported that the inclusion of 10, 20 and $40 \mathrm{~g} / \mathrm{kg}$ grapeseed powder in the broilers diet improved broiler performance.

The metabolic profile of the blood plasma (Table $5)$ showed significantly $(p<0.05)$ lower values of the energy profile parameters in the meat from group $\mathrm{E}$ (glycaemia, cholesterol and triglycerides) compared to group C. The literature (Hibbeln \& Salem, 1995) shows that the quantity and distribution of dietary omega- 6 and omega-3 polyunsaturated essential fatty acids influence serum. Another aspect to be considered is that polyunsaturated fatty acids are thought to lower the serum cholesterol level more effectively than monounsaturated fatty acids (Mensink et al., 1989). In this study too, the grapeseed and flaxseed meal had a rich content of PUFA, higher than MUFA content. Researchers (Keys et al., 1965; Hegsted et al., 1965) found that replacing the saturated fat by (omega-6) polyunsaturated fat in the form of linoleic acid caused a larger decline in total serum cholesterol levels than monounsaturated fatty acids, carbohydrates, or protein (Mensink et al., 1989). Omega-3 fatty acids are essential for the normal growth and development and displayed serum lipid lowering, antithrombotic, antiarrhythmic, and anti-inflammatory effects ( $\mathrm{Hu}$ et al., 1999). The obtained results show that grapeseed meal played a strong antioxidant role, being consistent with the statement that feeding high-polyphenols increase the oxidative stability and provide a source of compounds that are useful for human nutrition and health (Laudadio et al., 2015). The fact that blood cholesterol and triglyceride levels decreased in this study means an improvement in the health status of broilers over the experimental period due to the applied treatment, namely the inclusion of grapeseed meal in high omega-3 fatty acids diets.

Through the parameters of the mineral profile, the calcium and iron concentrations were significantly $(p<0.05)$ higher in samples from the experimental group (Table 5). The literature results are varied. 
Turcu RP, Olteanu M, Criste RD, Panaite TD, Ropotă M, Vlaicu PA, Drăgotoiu D
Grapeseed Meal Used as Natural Antioxidant in High Fatty Acid Diets for Hubbard Broilers
Chamorro et al. (2013) investigated the use of grapeseed extract in various proportions (0.025; $0.25 ; 2.5$ and $5.0 \mathrm{~g} / \mathrm{kg}$ compound feed) in the diets of broilers aged 21 days. The addition of increasing levels of grapeseed extract in the chicken diets did not change the analysed plasma parameters, but caused a significant decrease in the concentrations of plasma iron (up to $27 \%$ ) and zinc (up to 12.3\%) compared to the animals fed the control diet. The blood plasma results (Table 5) are in agreement with those reported by Fakhraddin \& Habib (2014), who studied the effect of various grape pomace levels $(0,2,4$ and $6 \%$ ) in broiler diets on performance, lipid peroxidation and on some biochemical parameters. The results showed a significant decrease of the blood triglycerides (from $52.00 \mathrm{mg} / \mathrm{dl}$ to $35.33 \mathrm{mg} / \mathrm{dl}$ ), and of the cholesterol (from $163.33 \mathrm{mg} / \mathrm{dl}$ to $129.33 \mathrm{mg} / \mathrm{dl}$ ). The protein profile was not significantly different between the groups ( $p>0.05$ ). The blood mineral content varied as follows: $0.063-0.066 \mu \mathrm{g} / \mathrm{ml}$ copper, $0.65-0.89 \mu \mathrm{g} /$ $\mathrm{ml}$ iron, and $1.83-2.04 \mu \mathrm{g} / \mathrm{ml}$ zinc.

The fatty acids composition of the meat is considered an important index for meat quality. The grapeseed meal improved the nutritional quality of the broiler meat (breast and thigh) in group $\mathrm{E}$ (Table 6). Significantly $(p<0.05)$ higher values of the total PUFAs and of omega- 6 fatty acids were noticed in the breast meat from the experimental group compared to the control group. PUFAs concentration was also higher in the thigh meat from group E compared to group $C$, but the difference was not statistically significant ( $p>0.05)$. The results for breast and thigh meat fatty acids content are similar with those reported by Olteanu et al. (2017) who used 2\% flaxseed meal and $3 \%$ grapeseed meal as natural antioxidant in Cobb 500 broiler diets. In the breast meat, PUFA content was $32.46 \mathrm{~g} / 100 \mathrm{~g}$ and for thigh meat was37.68 g/ $100 \mathrm{~g}$ total fatty acids. Chamorro et al. (2015), who studied the effect of including different levels $(0,5$, and $10 \%$ ) of grape pomace phenolic compounds and the addition (individually or combined) of hydrolysing enzymes (carbohydrase enzyme complex and tannase at 500 ppm) in broiler diets reported increased PUFA concentration and reduced MUFA content of the thigh meat.

The fat degradation indices (Table 7) showed a significantly $(p<0.05)$ lower peroxide value, after 7 days of refrigeration, in the breast meat samples from the group treated with grapeseed meal. Fat acidity was also significantly $(p<0.05)$ lower in the thigh meat samples from group $E$, both after 7 days of refrigeration, and after one month of freezing, which means that grapeseed meal had a strong antioxidant character, since the concentration of PUFA from thigh meat was higher in $E$ group compared to $C$ group. The determined peroxide value of meat samples (breast and thigh) in this study are in agreement with the literature data. Thus, Goni et al. (2007) investigated the effect of fermented grape pomace on broiler performance and antioxidant activity. The study showed that, in the meat samples refrigerated for 1, 4 and 7 days, lipid oxidation decreased linearly with the increase of the dietary grape pomace $(0.5,1.5$ and $3 \%)$. Olteanu et al. (2017) also reported lower fat acidity values in the meat samples from broilers treated with grape marc, while Brenes et al. (2008) concluded that the dietary grape pomace enhances the antioxidant activity in the broiler breast meat. Investigations by Kasapidou et al. (2016) on the inclusion of grape meal in broilers diet showed that the tested treatments did not affect the lipid oxidation of meat samples (breast and thigh) during refrigeration storage $\left(4^{\circ} \mathrm{C}\right)$ for 2 and 5 days.

Recent recommendations by health professionals call for foods which are low in cholesterol and high in polyunsaturated fatty acids (PUFA) and therefore are healthier (Yalçyn et al., 2007). In this study, the recorded cholesterol concentration in the meat (Table 8) highlighted a significant $(p<0.05)$ decrease in the thigh meat from the group with $2 \%$ grapeseed meal inclusion, in contrast to the group $\mathrm{C}$. The fatty acid profile of the meat and fat is directly affected by the source of fat in the poultry diet. Therefore, it is possible to change the fatty acid profile, especially the ratio of omega-3 fatty acids and to reduce the cholesterol level (Mridula et al., 2015). Cholesterol is necessary to maintain cellular integrity, having an important role in regulating the viscosity of the cell fluids (blood). For this reason, a low cholesterol content contributes to the good circulation of the blood in the body. Also, cholesterol plays a role in the metabolism of liposoluble vitamins: $A, D, K, E$, being a major precursor of vitamin $D$ and interfering with the immune system. Decreasing cholesterol and triglyceride levels through a healthy diet contributes to the optimal functioning of the entire body (Holick, 1996). Therefore, the cholesterol level should be balanced, recommended by doctors.

Panaite et al. (2016) investigated the effect of layer diets enriched in omega-3 fatty acids supplemented with $5 \%$ flaxseed meal and $2 \%$ camelina meal. The use of the experimental diets produced eggs with properties of functional foods because the yolk concentration of $\alpha$ linolenic acid was higher than in group C, while the cholesterol concentration was 
Turcu RP, Olteanu M, Criste RD, Panaite TD, Ropotă M, Vlaicu PA, Drăgotoiu D
Grapeseed Meal Used as Natural Antioxidant in High Fatty Acid Diets for Hubbard Broilers significantly lower than in group C. Abu et al. (2018) have reported that the inclusion of 10,20 and $40 \mathrm{~g} / \mathrm{kg}$ grapeseed powder in the broilers diet reduced blood lipids, enhanced antioxidant capacity, and decreased the detrimental bacteria in the ileum. Jiao et al. (2010) investigated the effect of grapeseed proanthocyanidins inclusion on blood cholesterol level and gene expression of cholesterol-regulating enzymes in hamsters. The researchers concluded that the inclusion of $0.5 \%$ and $1 \%$ grapeseed proanthocyanidins in diets can regulate the blood lipids metabolism of animal bodies, with the function of lowering cholesterol. Other studies (Farahat et al., 2017) on the effect of supplementation of broiler diets with grapeseed extract as a natural antioxidant at levels of 125, 250, 500, 1000 and 2000 ppm revealed a decrease in total cholesterol and low density lipoprotein cholesterol compared to those which received a synthetic antioxidant, BHT. Also, the inclusion of the viticultural by-product in diets has significantly decreased $(p<0.05)$ the level of malondialdehyde in the meat tissue. The recorded results did not reveal any significant differences in the performance of the chickens.

The positive effects of cholesterol-lowering in meat from broiler (breast and thigh) are important for human nutrition and health, reducing in particular the cardiovascular disease problems. Studies have shown that lowering cholesterol may reduce the risk of heart attack, so whether or not they suffer from heart disease, the adult population must necessarily keep their cholesterol levels under constant surveillance (Pavlovic et al., 2018). Within this context, we can consider that the inclusion of grapeseed meal in broiler diets acted as a feed additive with qualities of natural antioxidant due to the rich content of bioactive compounds with antioxidant properties.

\section{CONCLUSIONS}

In summary, from the nutritional perspective the results obtained in this study showed that the inclusion of $2 \%$ of grapeseed meal in the diet of broilers did not affect their performance (weight gain or feed consumption). From the nutritional and health perspective, our results are in agreement with other research suggesting the antioxidant properties of grapeseed meal. The inclusion of this by-product as natural antioxidant in high fatty acids diets for Hubbard broilers had beneficial effects both on the quality of the broiler meat, and on the metabolic profile of the blood plasma. Grapeseed meal led to a significantly $(p>0.05)$ lower cholesterol content in the thigh meat and also decreased all the energy parameters profile from the blood plasma, compared to group C. Reducing the level of cholesterol in the meat, as well as the values of the parameters of the energy profile, reveals the improvement of the broiler health status, as well as the positive effects of consuming low cholesterol-broiler meat on human health.

\section{ACKNOWLEDGEMENTS}

The paper shows part of the results obtained within project PN 1641_02.04, Contract 24 N / 2016, NUCLEUS program, financed by the Ministry of Research and Innovation.

\section{REFERENCES}

Abu H, Ibrahim SH, Ibrahim SA. Effect of dietary polyphenol-rich grape seed on growth performance, antioxidant capacity and ileal microflora in broiler chicks. Journal of Animal Physiology and Animal Nutrition 2018;102:268-275.

Ayerza R, Coates W, Lauria M. Chia seed (Salvia hispanica L.) as an $\otimes-3$ fatty acid source for broilers: influence on fatty acid composition, cholesterol and fat content of white and dark meats, growth performance, and sensory characteristics. Journal of Poultry Science 2002;81:826-837.

Brenes A, Viveros A, Goni I, Centeno C, Sayago-Ayerdy SG, Arija I. Effect of grape pomace concentrate and vitamin $E$ on digestibility of polyphenols and antioxidant activity in chickens. Journal of Poultry Science 2008;87(2):307-316

Bruno G, Sparapano, L. Effects of three esca-associated fungi on Vitis vinifera L: V. Changesin the chemical and biological profile of xylem sap from diseased cv. Sangiovese vines. Physiol. Molecular Plant Pathology 2007;71:210-229.

Burlacu Gh, Cavache A, Burlacu R, Surdu I. Ghid pentru al catuirea ratiilor de hrana la pasari. Balotesi: IBNA; 1999.

Burlacu GH, Cavache A, Burlacu R. Potentialul productiv al nutreturilor si utilizarea lor. Bucuresti: Editura Ceres; 2002.

Chamorro S, Viveros A, Centeno C, Romero C, Arija I, Brenes A. Effects of dietary grape seed extract on growth performance, amino acid digestibility and plasma lipids and mineral content in broiler chicks. Animal Journal - The Consortium Animal 2013;7(4):555-561.

Chamorro S, Viveros A, Rebole A, Rica BD, Arija I, Brenes A. Influence of dietary enzyme addition on polyphenol utilization and meat oxidation of chicks fed grape pomace. Food Research International Journal 2015;73:197-203

En-Qin X, Gui-Fang D, Ya-Jun G, Hua-Bin L. Biological activities of polyphenols from grapes. International Journal of Molecular Sciences 2010;11:622-646.

Evans M, Roberts A, Rees A. The future direction of cholesterol-lowering therapy. Current Opinion in Lipidology 2002;13:663-669.

Fakhraddin K, Habib AS. The effect of red grape pomace on performance, lipid peroxidation (MDA) and some serum biochemical parameters in broiler. Advanced Biomedical Research 2014;5(3):82-87. 
Turcu RP, Olteanu M, Criste RD, Panaite TD, Ropotă M, Vlaicu PA, Drăgotoiu D
Grapeseed Meal Used as Natural Antioxidant in High Fatty Acid Diets for Hubbard Broilers
Farahat MH, Abdallah FM, Ali HA, Hernandez-Santana A. Effect of dietary supplementation of grape seed extract on the growth performance, lipid profile, antioxidant status and immune response of broiler chickens. Animal 2017;11(5):771-777

Goñi I, Brenes A, Centeno C, Viveros A, Saura-Calixto F, Rebole A, et al. Effect of dietary grape pomace and vitamin $E$ on growth performance, nutrient digestibility, and susceptibility to meat lipid oxidation in chickens. Poultry Science 2007;86:508-516

Granato D, Castro IA, Katayama FCU. Assessing the association between phenolic compounds and the antioxidant activity of Brazilian red wines using chemometrics. LWT- Food Science and Technology 2010;43:1542-1549.

Hegsted DM, McGandy RB, MyerS ML, Stare FJ. Quantitative effects of dietary fat of serum cholesterol in man. American Journal of Clinical Nutrition 1965; 17:281-295.

Hibbein JR, Salem Jr N. Dietary polyunsaturated fatty acids and depression: whencholesterol does not satisfy. American Journal of Clinical Nutrition 1995;62:1-9.

Holick MF. Vitamin D and bone health. The Journal of Nutrition 1996;126(4):1159S-1164S.

Hu FB, Stampfer MJ, Manson JAE, Rimm EB, Wolk A, Graham AC,

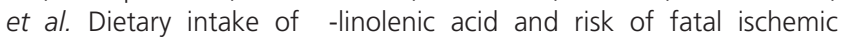
heart disease among women. American Journal of Clinical Nutrition 1999;69(5):890-897.

Jiao R.Z, Zhang S, Yu HJ, Huang Y, Chen ZY. Hypocholesterolemic activity of grape seed proanthocyanidin is mediated by enhancement of bile acid excretion and up-regulation of CYP7A1. The Journal of Nutritional Biochemistry 2010;21:1134-1139.

Kasapidou E, Sossidou EN, Zdragas A, Papadaki C, Vafeas G, Mitlianga $P$. Effect of grape pomace supplementation on broiler meat quality characteristics. European Poultry Science 2016;80.

Keys A, Anderson JT, Grande F. Serum cholesterol response to changes in the diet. IV. particular saturated fatty acids in the diet. Metabolism 1965; $14: 776-787$.

Ky I, Lorrain B, Kolbas N, Crozier A, Teissedre PL. Wine by-products: phenolic characterization and antioxidant activity evaluation of grapes and grape pomaces from six different French grape varietie. Molecules Journal 2014;19:482-506.

Laudadio V, Ceci E, Lastella NMB, Tufarelli V. Dietary high-polyphenols extravirgin olive oil is effective in reducing cholesterol content in eggs. Lipids in Health and Disease 2015;14:5.

Luque-Rodríguez JM, Luque de Castro MD, Pérez-Juan P. Extraction of fatty acids from grape seed by superheated hexane. Talanta 2005;68:126130.

Luther M, Parry J, Moore J, Meng J, Zhang Y, Cheng Z, et al. Inhibitory effect of Chardonnay and black raspberry seed extractson lipid oxidation in fish oil and their radical scavengingand antimicrobial properties. Food Chemistry 2007;104:1065-1073.

Marxen K, Vanselow KH, Lippemeier S, Hintze R, Ruser A, Hansen UP. Determination of DPPH radical oxidation caused by methanolic extracts of some microalgal species by linear regression analysis of spectrophotometric measurements. Sensors Journal 2007;7:20802095

Mensink RP, Groot MJM, Broeke LT, Severijnen-Nobels AP, Demacker PNM, Katan MB. Effects of monounsaturated fatty acids $v$ complex carbohydrates on serum lipoproteins and apoproteins in healthy men and women. Metabolism 1989:38:172-178.
Meyer AS, Yi OS, Pearson DA, Waterhouse AL, Frankel EN. Inhibition of human lowdensity lipoprotein oxidation in relation to composition of phenolic antioxidants in grapes (Vitis vinifera). Journal of Agriculture Food Chemistry 1997;45:1638-1643.

Mihailović V, Matić S, Mišić D, Solujić S, Stanić S, Katanić J, et al. Chemical composition, antioxidant and antigenotoxic activities of different fractions of Gentiana asclepiadea L. roots extract. EXCLI Journal 2013; $12: 807-823$

Mironeasa S. Valorificarea produselor secundare din vinificatie. Iasi: Editura Performantica; 2017.

Mridula D, Kaur D, Nagra SS, Barnwal P, Gurumayum S, Kumar Singh K. Growth performance and quality characteristics of flaxseed-fed broiler chicks. Journal of Applied Animal Research 2015;43(3):345-351.

Olteanu M, Criste RD, Panaite TD, Ropota M, Vlaicu PA, Turcu RP. Bioproductive parameters and fatty acids profile of the meat from broilers treated with flax meal and grape seeds meal. Scientific Papers: Animal Science and Biotechnologies 2017;50(1):15-21.

Olteanu M, Criste RD, Panaite TD, Turcu RP, Ropota M, Vlaicu PA, et al. Antioxidant role of the grape seeds meal in preventing the degradation of fatty acids-high diet formulations for broilers. Scientific Papers. Series D. Animal Science 2018;61(2):61-67

Panaite T, Criste RD, Ropota M, Cornescu GM, Alexandrescu DC, Criste V, et al. Effect of layer diets enriched in omega-3 fatty acids supplemented with $\mathrm{cu}$ on the nutritive value of the eggs. Romanian Biotechnological Letters 2016;21(4):11754-11762.

Panaite TD, Criste RD, Ropota M, Criste V, Vasile G, Olteanu M, et al. Determination of the feeding value of food industry by-products. Scientific Papers-Animal Science Series: Lucrări Ştiinţifice - Seria Zootehnie 2016:66(21):106-111.

Pastrana-Bonilla E, Akoh, CC, Sellappan S, Krewer G. Phenolic content and antioxidant capacity of muscadine grapes. Journal of Agricultural and Food Chemistry 2003;51:5497-4503.

Pavlovic J, Greenland P, Deckers JW, Kavousi M, Hofman A, Ikram MA, et al. Assessing gaps in cholesterol treatment guidelines for primary prevention of cardiovascular disease based on available randomised clinical trial evidence: the rotterdam atudy. European Journal of Preventive Cardiology 2018;25(4):420-431

Ponte PIP, Mendes I, Quaresma M, Aguiar MNM, Lemos JPC, Ferreira LMA, et al. Cholesterol levels and sensory characteristics of meat from broilers consuming moderate to high levels of alfalfa. Journal of Poultry Science 2004;83:810-814.

Poudel PR, Tamura H, Kataoka I, Mochioka R. Phenolic compounds and antioxidant activities of skins and seeds of five wild grapes and two hybrids native to Japan. Journal of Food Composition and Analysis 2008;21:622-625.

Radovanovic A, Radovanovic B, Jovancicevic B. Free radical scavenging and bacterial activities of southern Serbian red wines. Journal of Food Chemistry 2009;117:326-331.

Ren Y, Perez TI, Zuidhof MJ, Renema RA, Wu J. Oxidative stability of omega-3 polyunsaturated fatty acids enriched eggs. Journal of Agricultural and Food Chemistry 2013;61(47):11595-11602.

Singleton VL. Grape and wine phenolics: background and prospects Proceedings of the University of California; 1980; Davis, California: University of California, Davis; 1980. p.15-227

Tapiero H, Tew KD, Ba GN, Mathé G. Polyphenols: do they play a rolein the prevention of human pathologies? Biomed Pharmacother 2002:56:200-207. 
Teixeira A, Baenas N, Dominguez-Perles R, Barros A, Rosa E, Moreno DA, et al. Natural bioactive compounds from winery by-products as health promoters: a review. International Journal of Molecular Sciences 2014;15:15638-15678.

Viveros A, Chamorro S, Pizarro M, Arija I, Centeno C, Brenes A. Effect of dietary polyphenol-rich grape products on intestinal microflora and gut morphology in broiler chicks. Jounal of Poultry Science 2011;90:566578.

Wang ML, Suo X, Gu JH, Zhang WW, Fang Q, Wang X. Influence of grape seed proanthocyanidin extract in broiler chickens: effect on chicken coccidiosis and antioxidant status. Journal of Poultry Science 2008;87(11):2273-2280

Yalçyn, H, Kemal Ünal, M, Basmacyoolu H. The fatty acid and cholesterol composition of enriched egg yolk lipids obtained by modifying hens' diets with fish oil and flaxseed. Grasas y Aceites 2007;58(4):372-378.

***Hubbard Classic. Broiler management manual. Available from: www. hubbardbreeders.com

$* * *$ NRC -National Research Council. Nutrient requirement of poultry. $9^{\text {th }}$ ed. Revised. Washington: National Academy Press; 1994. 
